\title{
The Namibian Constitution, International Law and the Courts: a Critique
}

\author{
Ndjodi Ndeunyema \\ B. Juris, LLB (University of Namibia); MSc Criminology and Criminal Justice, \\ BCL, MPhil Law, DPhil Law Candidate (University of Oxford); Research \\ Director, Oxford Human Rights Hub, Oxford, United Kingdom \\ ndjodi.ndeunyema@law.ox.ac.uk
}

\begin{abstract}
This article examines the Namibian position in relation to the domestic application of international law. Through an analysis of Article 144 as the primary Constitutional touchstone provision, the meaning and binding nature of international agreements is unpacked, in the process identifying how these sources become part of Namibian law. Moreover, the paper advances that Article 144's phraseology renders both customary international law and general principles of law as sources of binding law in Namibia. A critique of the judicial application of international law, particularly by the Supreme Court, also reveals inconsistencies and errors. In addition to international law's direct application, the paper identifies the parallel interpretative functionality of international law and enquires into the appropriate method for interpreting international law by domestic courts. The paper concludes by determining the relevance of soft law sources as deliberative, and potentially persuasive interpretative aids.
\end{abstract}

\section{Keywords}

customary international law - international agreements - monism - Namibia - soft law

\section{Introduction}

This article considers the application of international law in Namibia by primarily examining Article 144 of the Namibian Constitution. Although there is 
constitutional stability, the application of international law domestically remains unsettled. A popular assertion in the existing literature is that Namibia applies a monist approach to international law. While this is a starting point, it is by no means adequate to capture and address the myriad of legal quandaries that the application of international law domestically gives rise to. The paper will commence by laying the theoretical foundation for the application of international law domestically. This is done through a pointed examination of the issue of the relationship between international law and municipal law, in the process exploring the theoretical and practical concerns qua international law's domestic application. While the inter-relationship between international law and municipal law has received some attention amongst international law scholars, and as it pertains to Namibia specifically, this paper identifies some of the gaps in the existing analysis on Namibia's international law - municipal law 'model.'

Through a Namibian jurisprudential and doctrinal analysis that draws on comparative perspectives and scholarship, the article will argue for an understanding of international law that forms part of Namibian law as international agreements $^{2}$ and general rules of public international law, the latter constituting both customary international law and general principles of law. The paper then examines both the position of international law in Namibia and the domestic interpretation thereof by Namibian courts. In so doing, the assessment will reveal the limited attention by domestic courts as to the application of international law municipally and where it has, the analysis is in part inadequate and at times inaccurate.

As to the interpretation of international agreements that bind Namibia, the enquiry will assert that the appropriate interpretative methodologies are those contained in Articles 31 and 32 of the 1969 Vienna Convention on the Law of Treaties between States, ${ }^{3}$ provisions which reflect customary international law. It will be necessary also to examine the authoritative status of "soft law"

1 The principal literature on international law in Namibia: G Erasmus, 'The Namibian Constitution and the application of international law' (1989/1990) ${ }_{15}$ South African Year Book of International Law 84; T Maluwa, The Incorporation of International Law and its Interpretational Role in Municipal Legal Systems in Africa: An Explanatory Survey (1998) 23 South African Year Book of International Law 45; O Tshosa, 'The status of international law in Namibian national law' (2010) 2/1 Namibia Law Journal 5; Y Dausab, 'International Law vis-à-vis Municipal Law: An Appraisal of Article 144 of the Namibian Constitution From a Human Rights Perspective' in A Bösl et al. (eds.), Constitutional Democracy in Namibia: A Critical Analysis After Two Decades (Macmillan 2010) 261; D Zongwe, International Law in Namibia (Langaa 2019).

2 In this article, a reference to international agreements includes treaties, covenants, or instruments.

3 Vienna Convention on the Law of Treaties, 23 May 1969, UnTs Vol. 1155. 
sources in Namibian courts with a particular focus on general comments of treaty bodies that are established by international agreements. As this analysis focuses on the application of international law in a domestic adjudication, this section examines the how of international law's application in Namibia. To facilitate normative clarity, international human rights law will serve as the conceptual framework of the article.

At the heart of debates concerning the international law - municipal law relationship is the issue of supremacy and the independence or (extent of) separation between the two legal orders. The soundness of this analysis is germane because question of the nature of the relationship arises whenever applying international law in a domestic context. ${ }^{4}$ Four overarching theories have been developed to describe a given jurisdiction's municipal law - international law relationship. ${ }^{5}$ Monism and dualism, which are the two most prominent theories, as well as inverse monism and harmonisation. ${ }^{6}$ The historical analysis is stressed given the reality that these theories are impure, inadequate and antiquated paradigms for understanding the municipal law - international law relationship, not least because of the globalized nature of the contemporary world legal order.

Monism captures unitary conceptions of law wherein international law and municipal law are viewed as a single, unified system. ${ }^{7} \mathrm{~A}$ monist approach gives international law primacy over municipal law in both international and municipal decisions. International law has direct effect and automatically forms part of the municipal legal order without further need of incorporation or transformation within the State, for example through domesticating legislation. Therefore, once a State has bound itself to an international agreement in line with its domestic provisions or where a given rule is established as customary international law or a general principle of law, then such international

4 D O'Connell, 'The Relationship between International Law and Municipal Law' (1960) 48 Georgetown Law Journal 444.

5 D O'Connell, International Law (Stevens \& Sons 1970) 39; D Harris, Cases and Materials on International Law (Sweet and Maxwell 2010) 61.

6 For the historical debate of the theories, J Nijman and A Nollkaemper, (Eds) 'Introduction' in New Perspectives on the Divide between National and International Law (OUP 2007).

7 O'Connell ( $\mathrm{n}_{5}$ ) 39; T Finegan, 'Holism and the Relationship between Municipal and International Human Rights Law' (2011) 2/4 Transnational Legal Theory 478. 
law would bind that State, including its courts. Domestic application would follow without the need for further legislative affirmation.

Under a dualist model, international law retains primacy over municipal law in international decisions, while municipal law has primacy over international law in municipal decisions. Sometimes referred to as pluralism, dualism starts from the proposition that law is an act of sovereign will. Municipal law is distinguished from international law in that it is a manifestation of the will internally directed, as distinct from participation in a collective act of sovereigns. ${ }^{8}$ Dualism holds that international law and municipal law are separate, dichotomous legal authorities with insignificant overlap, relationship and interplay between them. ${ }^{9} \mathrm{~A}$ classic dualist assertion is that the two legal systems are to be differentiated based on the particular relations that they govern: whereas a State's municipal law deals with social relations between individuals, international law regulates social relations between States, which alone are subject to it. ${ }^{10}$ Dualism further asserts the predominance of the sovereign State and its own municipal law. Thus, for international law to be applicable in municipal courts, the doctrines of transformation (or incorporation) and adoption must be given effect.11

The transformation doctrine reflects an 'extreme' dualist position in asserting that individual rules of international law will only become part of municipal law where they are consciously transformed or incorporated into the municipal law by way of a legislative act, the promulgation of a treaty or other appropriate constitutional gesture. The transformation doctrine presupposes that international law is independently inapplicable in a municipal court, and hence must be 'transformed' into municipal law through the agencies of the sovereign will, the Legislature and Executive. The transformation doctrine is common in the parliamentary sovereignty tradition, quintessentially exemplified by the UK. ${ }^{12}$ Treaties in a dualist State would need to be promulgated by the sovereign through legislation. Additionally, customary rules must likewise be promulgated. ${ }^{13}$ The adoption doctrine represents an alternative dualist proposition from transformation and posits that municipal law presumes a mandate from the sovereign to incorporate international law. Therefore, domestic courts are entitled to resort to international law without requiring that

\footnotetext{
8 O'Connell (n 5) 42; H Triepel, International Law and State Law 1868-1946.

$9 \quad$ Finegan $\left(\mathrm{n}_{7}\right) 478$.

$10 \quad$ Tshosa (n 1) 5 .

11 R O'Keefe, 'The Doctrine of Incorporation Revisited' (2009) 79/1 British Yearbook of International Law 10.

12 ibid.

13 O'Connell (n 5) 49.
} 
the sovereign consciously promulgate it as one of municipal law. However, domestic courts would remain bound by higher norms such as municipal legislation, for instance. ${ }^{14}$

Inverse monism is a species of monism in the reverse, asserting that municipal law has primacy over international law in both international and municipal decisions. Finally, harmonisation radically rejects the supposition of conflict between international law and municipal law altogether. Harmonisation questions the overall soundness of monist and dualist positions by arguing that the attempt to resolve conflict by asserting the automatic superiority of one legal order over the other does not reflect the reality. ${ }^{15}$

At this stage, it is important to heed Tshosa's three points of caution when considering these theories in the Namibian context. First, as a matter of practicality, the applicable theory is not to be purely determined theoretically and in abstract. ${ }^{16}$ Determining the domestic application of international law and treaties in particular would be conditioned by a rule of municipal law. A basic principle reflected in most legal systems with constitutions as the overarching normative framework is that constitutional law governs the internal application of treaties. ${ }^{17}$ This principle applies to Namibia, as argued below. Second, Tshosa observes that the practical approach of national courts, including Namibia, reveal that even in monist States, courts frequently fail to effectuate binding treaties. ${ }^{18}$ Third, Tshosa concludes that for Namibia, these theories 'are relevant only in the specific context of customary, but not conventional, international law' ${ }^{19}$ The real concern, Tshosa observes, relates to 'how international law standards can be infused or, rather, incorporated' into municipal law to reinforce the effectiveness of the national legal system given that national legal rules are at times not well-defined and inadequate to address practical legal questions. $^{20}$

Nevertheless, Tshosa's points of caution do not make the theories of international law - municipal law redundant. Rather, they allow for the continued illumination of that relationship. Indeed, there is an observed 'symbiotic'

\footnotetext{
14 ibid.

15 O'Connell (n 5) 46; R Schaffer, 'The Inter-Relationship between Public International Law and the Law of South Africa: An Overview' (1983) 32/2 International and Comparative Law Quarterly 282.

16 Tshosa (n 1$) 6$.

17 A Nollkaemper, 'The effect of treaties in domestic law' In C Tams, A Tzanakopoulos and A Zimmermann, (eds) Research Handbook on the Law of Treaties (Edward Elgar 2014) 130; Tshosa (n 1$) 6$.

18 Tshosa (n 1) 6; Dausab (n 1 ) 261.

19 Tshosa ( $\mathrm{n} 1) 6$.

20 ibid.
} 
relationship between international law and municipal law: domestic law can be a material source of international law, while international law can simultaneously influence domestic law. ${ }^{21}$ Therefore, in considering the relationship, one ought to closely consider the constitutional position. The next section turns to 'the prescriptions' of the Namibian Constitution.

\section{The Application of International Law before the Constitution}

It is necessry to properly contextualize the Constitution's 'newly' established international law position because of the legal continuity reflected in Article 66(1) which recognizes the continued force and validity of the common law as at independence, save where it conflicts with the Constitution or legislation. It follows that the pre-constitutional common law position on international law's application would apply, unless the contrary is gleaned from either the Constitution or legislation.

The legal system of South West Africa-pre-independence Namibia - was effectively an extension of South African Westminster parliamentary sovereignty models imposed during colonial rule. ${ }^{22}$ The then unwritten and composite constitution of South Africa did not contain any provisions on the application of international law. Concerning international agreements, the preConstitution position in Namibia was that signature, ratification or accession to international agreements constituted an executive act. To form part of municipal law, domestic incorporation by way of a legislative act was required, ${ }^{23}$ a position confirmed in Binga ${ }^{24}$ Strydom J-in distinguishing CIL from international agreements in the form of UNGA and UNSC resolutions revoking South Africa's League of Nations mandate over South-West Africa—stated:

Obligations incurred by international treaty and resolutions by international organisations such as the United Nations stand on a different footing from international customary law and generally speaking a South African Court, and for that matter a Court of this territory, will only give

21 O Elias and C Lim, "General Principles of Law, "Soft" Law and the Identification of International Law' (1997) 28 Netherlands Yearbook of International Laws 22.

22 Erasmus $\left(\begin{array}{ll}n & 1\end{array}\right)$ 85. See also A Sanders, 'The applicability of customary international law in South African law - the Appeal Court has spoken' (1978) 11/2 The Comparative and International Law Journal of Southern Africa 198.

23 Pan American World Airways Incorporated v SA Fire and Accident Insurance Co Ltd 1965 3 SA 150 (A) 161.

24 Binga v Administrator-General, South West Africa 1984 (3) SA 949 (swA) at 968-69. 
effect thereto if such treaty or resolution was incorporated by legislative act into the laws of the land. ${ }^{25}$

Binga confirms the domestic incorporation requirement for international agreements through legislation before their application. However, an unstated caveat to this position was that unincorporated treaties could be taken into account when interpreting ambiguous legislation. ${ }^{26}$

Concerning customary international law, the common law principles and judicial decisions had determined its domestic application. ${ }^{27}$ After a prolonged period of uncertainty and controversy, the Nduli decision by the South African Supreme Court of Appeal for the first time affirmed that customary international law did form part of South African law. ${ }^{28}$ Owing to the vassal nature of the legal system in Namibia before independence, Nduli applied to South West Africa/Namibia. ${ }^{29}$ However, there were caveats to Nduli drawn from the English law at the time. First, customary international law would not apply where it was inconsistent with an Act of the South African Parliament. This was in line with the doctrine of legislative sovereignty. ${ }^{30}$ Secondly, per the stare decisis doctrine, the courts would be bound to follow an established judicial precedent even though such precedent were discordant with a customary international law rule. ${ }^{31}$ Thirdly, the prerogative power of the Executive through the Act of State doctrine could override customary international law. ${ }^{32}$ Pertinently,

25 Binga (n 24) 968 (emphasis added).

26 Salomon $v$ Commissioners of Customs and Excise 1967 (2) QB 116.

27 RP Schaffer, "The Inter-Relationship Between Public International Law and the Law of South Africa: An Overview' (1983) 32 International and Comparative Law Quarterly 283; J Dugard, 'International Human Rights Norms in Domestic Courts: Can South Africa Learn from Britain and the United States?' in E Kahn, (ed) Essays in Memory of Oliver Schreiner (Juta 1980) 232.

28 Nduliv Minister of Justice 1978 (1) SA 893 (A) at 9o6. See also South Atlantic Islands Development Corporation Ltd v Buchan 1971 (1) SA 234 (C) at 238; Inter-Science Research and Development Services (Pty) Ltdv Republica Popular de Moçambique 19802 SA 111 (T) at 124; Kaffraria Property Co (Pty) Ltd v Government of the Republic of Zambia 19802 SA 709 (E) at 712,715 .

29 Erasmus (n 1$) 87$.

30 However, it was required that legislation 'should be interpreted to accord with international law wherever possible' (Nduli (n 28) 898) in light of the presumption that the legislature did not intend to derogate from customary international law. Cf Revv Lionda 1944 AD 348, 352-55; Sv Penrose 1966 (1) SA 5 (N) 11.

$31 \quad$ Trendtex Trading Corporation v Central Bank of Nigeria [1977] QB 529 (CA); Sanders (n 22) 200.

32 Erasmus ( $\mathrm{n} 1$ ) 90; Sanders ( $\mathrm{n} 22$ ) 200. For a judicial critique of the act of state doctrine and its continued application in Namibia, Mushwena (n 31$)$. 
there appears to be pre-constitutional judicial paucity on the domestic application of general principles of law as a binding source of international law.

In summary, the general approach to international law in pre-constitution Namibia was that a monist position applied to customary international law thus mandating its automatic application within the municipal order, while a dualist position applied for international agreements that required legislative incorporation into the municipal order. These judicial decisions thus reveal an 'international law-averse' attitude prior to the Constitution coming into effect.

\section{The International Law Position under the Constitution}

With the advent of independence, the Constitution jettisoned the international law-averse disposition by adopting legal features that can be described as 'international law friendly'33 or 'international law positive.' ${ }^{34}$ Although the Constitution's bill of rights framework has patently drawn from international human rights law, an examination of the Minutes of the Constituent Assembly ${ }^{35}$ that drafted the Constitution are silent on the precise motivations for this embrace of international law. However, a contemporaneous reading of the Constitution would suggest that it was likely in response to Namibia's history of colonialism and apartheid rulership, systems which flagrantly disregarded and ubiquitously violated international law, including international humanitarian law norms that were ostensibly applicable during the armed conflict that preceded independence. The claim is often made that 'Namibia is a child of international solidarity', ${ }^{36}$ a legal and political truism that aptly reflects the UN and the international community's role on the 'Question of Namibia'. ${ }^{37}$

33 Erasmus (n 1) 91; D Dermont, 'The relationship between international law and municipal law in light of the Interim South African Constitution 1993' (1995) 44/1 International Law and Comparative Law Quarterly 1.

34 Tshosa (n 1$) 9$.

35 Namibia Constituent Assembly Debates 21 November 1989-21 January 1990 Volume 1 and 2 (1990).

36 'Statement by His Excellency Hage G. Geingob, President of the Republic of Namibia at the General Debate of the UN General Assembly' 29 September 2015, available from: <http://www.gov.na/documents/10181/22710/STATEMENT+BY+HIS+EXCELLENCY+HAG $\mathrm{E}+\mathrm{G} .+$ GEINGOB,$+\mathrm{PRESIDENT}+\mathrm{OF}+\mathrm{THE}++\mathrm{REPUBLIC}+\mathrm{OF}+\mathrm{NAMIBIA}+\mathrm{AT}+\mathrm{THE}+\mathrm{GENER}$ $\mathrm{AL}+\mathrm{DEBATE}+\mathrm{OF}+\mathrm{THE}+\mathrm{UN}+\mathrm{GENERAL}++\mathrm{ASSEMBLY}+(2015+09+29) / 4 \mathrm{f}_{5} \mathrm{a}$ ebo4-84of-46of-9a7c-fa88aogo8o2e>.

United Nations General Assembly, 'Question of Namibia', 13 December 1985, A/REs/40/97. 
The Constitution's favourable predisposition to international law is evident in a plurality of provisions, including the Preamble and other explicit international law-esque provisions. ${ }^{38}$ Of these, the central provision is Article 144:

Unless otherwise provided by this Constitution or Act of Parliament, the general rules of public international law and international agreements binding upon Namibia under this Constitution shall form part of the law of Namibia.

Though laconic, Article 144 invites the conclusion that it 'sought to give expression to the intention of the Constitution to make Namibia part of the international community'39 and chimes well with principles of State sovereignty and State consent that are amongst the overarching premises of international law. To commence the Article 144 analysis, the meaning of 'general rules of public international law' and of 'international agreements' is deconstructed.

\subsection{Deconstructing the Meaning of 'General Rules of Public International Law' and 'International Agreements'}

It is of little controversy that Article 144's reference to international agreements ${ }^{40}$ is to be understood as a generic term that encapsulates all forms of written agreements that have been concluded between Namibia and other States (or international organisations). It demonstrates Namibia's consent to be bound by the content thereof. For an international agreement ${ }^{41}$ to form part of Namibian law, the procedural requirements to be followed are to be derived from various provisions of the Constitution. First, acting with the powers conferred by Article 32(3)(e), the President (or his delegate) would negotiate an international agreement ${ }^{42}$ and then sign it. These powers are exercised with the assistance of Cabinet Ministers who are, per Article 4o(i), empowered 'to assist the President in determining what international agreements are to be concluded, acceded to or succeeded to [...]'. Second, upon Presidential signature,

38 Constitutional provisions related to international law include: Article 1(4); Article 32(3(e); Article 95(d); Article 96(d); Article 99; and Article 140. Analysis in Tshosa (n 1$) 9$ and Erasmus (n 1) 93-4.

39 Government of the Republic of Namibia and Anotherv Cultura 20001993 NR 328 (SC) at 333.

40 'Commentary on Article 2(1)(a) of the Draft Articles on the Law of Treaties with commentaries in the 1966' Yearbook of the International Law Commission.

41 The Namibian Constitution does not distinguish various classes of international agreements such as political, technical, administrative or executive. cf section 231(3), 1996 South African Constitution. 
the National Assembly is vested by Article 63(2)(e) with the power and function 'to agree to the ratification of or accession to international agreements which have been negotiated and signed in terms of Article 32(3)(e)'. Constitutionally, therefore, the President must act with the approval of the National Assembly, ${ }^{43}$ thereby rendering the power and function to conclude (and withdraw from) international agreements, collective. ${ }^{44}$ The Constitution's dual-responsibility approach for the conclusion of international agreements augments democratic benefits of legislative scrutiny and executive accountability, as well as arguably, ameliorating the democratic deficits in international law-making.

The meaning and ambit of the phrase 'general rules of public international law' in Article 144 is more controversial. Namibia-centric scholars, including Tshosa and Erasmus, take the restrictive approach that the phrase is synonymous with customary international law. ${ }^{45} \mathrm{~A}$ recourse to comparative constitutionalism reveals a similar reference to 'general rules of public international law' in constitutions such as those of Germany ${ }^{46}$ and Kenya. ${ }^{47}$ Other constitutions (Malawi ${ }^{48}$ and South Africa ${ }^{49}$ ) specifically engage the term 'customary international law' to distinguish international law that is not sourced from international agreements. In my view, taking a generous, broad and purposive approach $^{50}$ to the interpretation of the Constitution, the reference to 'general rules of public international law' is to be correctly understood expansively as

43 This power is not vested with the Parliament as the Namibian Parliament is bicamerally composed of a lower chamber and an upper chamber-the National Assembly and the National Council, respectively.

44 See $S v$ Carracelas and Others (1) 1992 NR 322 (HC) 327.

45 Erasmus (n 1 ) 98; Tshosa (n 1 ) 11. Tshosa takes an even more restrictive approach by asserting that ' $[$ the] term general in this context means rules widely supported and accepted by the representatively large number of States'. Tshosa (n 1 ) 11 (emphasis in original).

46 H Rupp, 'International Law as Part of the Law of the Land: Some Aspects of the Operation of Article 25 of the Basic Law of the Federal Republic of Germany' (1976) 11 Texas International Law Journal 541; R Wolfrum, H Hestermeyer and S Vöneky, 'The reception of international law in the German legal order: An introduction' In E de Wet, H Hestermeyer, and R Wolfrum (Eds) The implementation of international law in Germany and South Africa (Pretoria University Law Press 2015) 17.

47 Kituo Cha Sheria \& 8 others $v$ Attorney General [2013] eKLr [70]. See M Wabwile, 'The Emerging Juridical Status of International Law in Kenya' (2013) 13/1 Oxford University Commonwealth Law Journal 167.

48 cf Section 211 of the Malawian Constitution.

49 Section 322 of the 1996 South African Constitution: 'Customary international law is law in the Republic unless it is inconsistent with the Constitution or an Act of Parliament'. See Kaunda and Others $v$ President of the Republic of South Africa 2005 (4) SA 235 (CC); D Shelton, 'Introduction' in D Shelton (ed) International Law and Domestic Legal Systems: Incorporation, Transformation, And Persuasion (OUP 2011) 14.

Minister of Defence v Mwandinghi 1993 NR 63 (SC) at 69; Cultura 2000 (n 39). 
including both customary international law and general principles of law. ${ }^{51}$ This understanding is one that principally leans on the text of Article 38(1)(a)(c) ICJ Statute which, in addition to international conventions, specifies 'international custom, as evidence of a general practice accepted as law', and 'the general principles of law of civilised nations.' ${ }^{22}$ Article $38(1)$ is widely accepted as reflecting customary international law on the formal sources of international law. Moreover, there is no a priori hierarchy in the three sources, ${ }^{53}$ although some may claim that general principles of law constitute a 'secondary' source with the main function of 'filling gaps' 54 in the absence of a treaty or customary norm. ${ }^{55}$ Accordingly, it is submitted that both customary international law and general principles of law are part of binding Namibian law. ${ }^{56}$

Concerning customary international law, the textbook method for establishing it is described in the Article 38(1)(b) ICJ Statute as 'evidence of a general practice accepted as law'.57 This traditionally, is made up of two elements. The first is the objective element of state practice (constuendo), which is a general practice that is sufficiently widespread and representative; the practice need not be uniform. ${ }^{58}$ The second is opinio juris, the subjective element that requires the practice of states to be due to a belief that a legal obligation exists, ${ }^{59}$ thereby distinguishing custom from mere usage or habit. The precise meaning and application of these elements in establishing custom remains uncertain.

51 While the specific reference to 'general rules of public international law' may be argued as excluding general principles of law, this is untenable as it would constitute a narrow interpretation of Article 144.

52 The North Sea Continental Shelf Cases (Germany/Denmark; Germany/Netherlands) 1969 ICJ Rep 101, 133 (Separate Opinion of Judge Ammoun).

53 J Crawford, Brownlie's Principles of Public International Law (OuP 2012) 35; S Yee, 'Article 38 of the ICJ Statute and Applicable Law: Selected Issues in Recent Cases' (2016) 7 Journal of International Dispute Settlement 488.

54 J Pauwelyn, Conflict of Norms in Public International Law: How wTo Law Relates to other Rules of International Law (CUP 2003) 127-29.

55 R Yotovana, 'Challenges in the Identification of 'the General Principles of Law Recognized by Civilized Nations': the Approach of the International Court' (2017) 3/1 Canadian Journal of Comparative and Contemporary Law 269 at 279.

$56 \quad$ Mushwena $\left(\mathrm{n}_{31}\right) 320$.

57 See generally: International Law Commission, 'Identification of International Customary law: Analytical Guide to the Work of the International Law Commission'. Available from http://legal.un.org/ilc/guide/1_13.shtml; Michael Wood, First report on the formation and evidence of customary international law. A/CN.4/663. (International Law Commission 2013); Michael Wood, Second report on identification of customary international law. A/CN.4/672. (International Law Commission 2013).

58 ibid.

59 The North Sea Continental Shelf Cases (Germany/Denmark; Germany/Netherlands) 1969 ICJ Rep 3, 44; Crawford (n 53) 25-32. 
Some scholars have poured cold water on the claim that domestic courts systematically follow this textbook method in their determination of custom. ${ }^{60}$ Others establish that, when determining rules of custom, the ICJ in particular has not used a single methodology but a mixture: induction, deduction and (the main method) assertion. ${ }^{61}$ Nevertheless, the central assumptions or the many critiques ${ }^{62}$ of custom are outside the remit of the paper. Rather, the paper will align with the settled approach that the two elements remain established and are indispensable in determining the existence of a rule of customary international law. ${ }^{63}$

While customary international law is settled as part of binding Namibian law, general principles of law are not as established. These have received scant attention or mention in Namibian courts as will be observed in the case studies below. ${ }^{64}$ Partly given their unwritten character, the determination of general principles remains a controversy under international law, one of the pertinent doctrinal issues being their determinative methodology 65 and whether these are general principles of municipal law, of international law, or of global legal systems. ${ }^{66}$ As these issues are not the focus herein, the position adopted aligns with the widely accepted view advanced by Redgwell that general principles in the Article $38(1)(\mathrm{c})$ sense may be derived and percolate from both municipal law and international law. ${ }^{67}$

As it has now been resolved that Article 144 incorporates the triad of international law sources of international agreements, customary international law,

6o C Ryngaert and D Siccama, 'Ascertaining Customary International Law: An Inquiry into the Methods used by Domestic Courts' (2018) 65/1 Netherlands International Law Review 1.

61 S Talmon, 'Determining customary international law: the ICJ's methodology between induction, deduction and assertion' (2015) 26/2 European Journal of International Law 417.

62 See K Frederic, 'Custom on a Sliding Scale' (1987) 81/1 American Journal of International Law, 146, the critique of which is summarized by Roberts (Tradition and Modern) 760; A Roberts, 'Traditional and Modern Approaches to Customary International Law: A Reconciliation' (2001) 95 American Journal of International Law 779 and source cited therein.

63 See George Galindo and Caesar Yip, 'Customary International Law and the Third World: Do Not Step on the Grass' (2017) 16/2 Chinese Journal of International Law 251.

64 See also B Simma and P Alston, 'The Sources of Human Rights Law: Custom, Jus Cogens and General Principles' (1988/1989) 12 Australian Yearbook of International Law 105, who advocate a greater grounding of the legality of human rights norms in general principles of law as these would ensure a strong grounding in the consensualist conception of international law.

65 See C Redgwell, 'General Principles of International Law' in S Weatherill and S Vogenauer (ed), General Principles of Law: European and Comparative Perspectives (Hart 2017).

66 Redgwell, (n 65) 10.

67 Redgwell, (n 65) 10; J Pauwelyn, Conflict of Norms in Public International Law: How WTO Law Relates to other Rules of International Law (CUP 2003) 125-26. 
and general principles of law as part of binding Namibian law, the next section considers the scope of application of Article 144.

\subsection{The Scope of Application of Article 144}

Article 144 introduces the automatic and mandatory application of both general rules of public international law and international agreements duly agreed to by the state of Namibian. This is evinced by the Constitution's drafters' choice of peremptory language in Article 144: 'shall form part of the law of Namibia'. No (further) legislative action is required for incorporation or transformation. This, thus, mandates the direct application of both general rules of public international law and international agreements by Namibian courts, ${ }^{68}$ a manifestation of the so-called direct-effect doctrine. This is subject to whether the international agreement is self-executing. ${ }^{69}$ In some instances, an international agreement would enjoin Namibia to undertake legislative and other measures to ensure the domestic effectiveness of international law. ${ }^{70}$

From the language of Article 144, there are two exceptions for the direct application of international law. ${ }^{71}$ The first is the constitutional supremacy exception: international law will not apply where it is 'otherwise provided' by the Constitution. That is, where it is incompatible with the Constitution itself. ${ }^{72}$ The exception aligns with the Constitution's self-proclaimed supremacy in Article 1(6). The test to determine the incompatibility of an international law position with the Constitution has not received significant judicial consideration. Only the High Court in Kauesa has arguably offered some guidance:

The specific provisions of the Constitution of Namibia, where specific and unequivocal, override provisions of international agreements which have become part of Namibian law. ${ }^{73}$

68 Tshosa (n 1$)$.

69 The direct effect doctrine is subject to whether or not an international agreement, in particular, is self-executing or non-self-executing. See, for example, J Jackson, 'Status of Treaties in Domestic Legal Systems: A Policy Analysis' (1992) 86 American Journal of International Law 310.

70 See Namibian Prevention and Combating of Terrorist and Proliferation Activities Act, 2014 (Act 4 of 2014), which expresses the preambular aim 'to provide for measures to give effect to the international conventions'.

71 A third qualification (which Erasmus and Tshosa appear to overlook) can also be added: norms jus cogens are binding upon Namibia, irrespective of whether they are (theoretically) in conformity with the Constitution or Acts of Parliament.

72 A Kawana, Motivation of the Namibian Constitution Third Amendment Bill, 2014 in the National Assembly. July 29, 2014.

Kauesa v Minister of Home Affairs 1994 NR 102 (HC) at 141 (Emphasis added); Tshosa (NLJ). 
Thus, to override international law, ${ }^{74}$ a Constitutional provision must specifically and unequivocally contradict international law. ${ }^{75}$

The second qualification is the legislative exception: international law will not apply where it conflicts with an Act of Parliament. ${ }^{76}$ As the Supreme Court stated in Thudinyane $v$ Edward, ${ }^{77}$ in the context of the Convention on the Rights of the Child's "best interest of the child" doctrine:

[I]n Namibia, international agreements [...] appear to have similar force of law as accorded to legislation, in the absence of any constitutional provision or Act of Parliament contradicting the law or agreement in question. ${ }^{78}$

The Supreme Court's approach, albeit in somewhat tentative language of 'appear to have', suggests that legislation and international agreements are on par. However, this would present practical interpretative difficulties where the provisions of legislation and international agreements are in direct conflict. The common law, which remains of application in light of Article 66(1) discussed earlier, offers a solution in the form of the doctrine of consistent interpretation. ${ }^{79}$ The doctrine requires legislation to be interpreted in harmony with international obligations wherever possible. ${ }^{80}$ Article 144 , it can be argued, thus requires that Namibian courts are obliged to take judicial notice of international law and are enjoined to have recourse to it as a source of national law. ${ }^{81}$

74 The test applies to international law, understood as also including general rules of public in ternational law, not only international agreements as in Kauesa.

75 cf N.V. Algemene Transport- en Expeditie Onderneming van Gend \& Loos v Netherlands Inland Revenue Administration [1963] ECR 1 on the requirements for direct effect of European Union law that is unconditional, clear and precise; Von Colson $v$ Land NordrheinWestfalen (C14/83) [1984] ECR on indirect effect of European Union law. Further, compare and contrast with the European Union law distinction between the doctrines of direct effect and direct application. Under direct effect, EU law provisions may, even without transposition by a Member State, give rise to immediate rights which can be enforced by individuals within the national legal systems of Member States. For direct applicability considers whether an EU law needs a national parliament to enact legislation to make it law in a member state.

76 Article 63(2)(e) of the Constitution.

77 (SA 17/2005) [2012] NASC 22 [18].

78 ibid [18] (emphasis added).

79 Nduli (n 28) at 898; see also Nollkaemper (n 17) 146. cf section 233 of the South African Constitution.

8o Dausab (n 1$) 267$.

81 Tshosa (n 1 ) 12. Tshosa does not cite authority for his contention that Namibian courts take judicial notice of binding international law, while Erasmus concludes that this 'flows 
An important qualification to the common law's application is necessary: customary law is placed on par with common law by Article 66(1). Thus, what this would ordinarily necessitate is a determination of the position that customary law took on the application of international law in Namibia, in addition to that of common law. The common law is not to be regarded as the default or hegemon regime. It remains an open question whether a single, coherent customary law principle on a given issue (such as resolving conflicts between treaties and the Constitution or legislation) can be extracted from Namibia's heterogeneity of communities with divergent customary laws. However, there can be little doubt that such customary laws exist(ed), not least if one considers the variety of treaties that were concluded between European colonial settlers and indigenous Africans who laid claim to the territory that is contemporary Namibia. ${ }^{82}$

The conclusion is often reached that Namibian law adopts a monist approach to the relationship between international law and Namibian municipal law. ${ }^{83}$ However, in light of the preceding analysis, the precise position would be that Namibia adopts what may be described as a 'weak' 84 monism or 'qualified' monism approach, given that international law is subject to its consistency with the Constitution and Acts of Parliament. Compared with the preindependence position, the Constitution's position is thus a departure from the legislative incorporation requirement for international agreements but is substantially a continuation of customary international law's automatic application, save for the applicable exceptions discussed.

A further conceptual caveat is necessary here: the classification of Namibia as a 'weak monist' State neglects the reality that casting the interaction between international law and municipal law in the either/or, oppositional categories of monism or dualism, 'not only hides a wide variety of complexity in the implementation of the doctrines, but also serves to overstate the differences between them', as Chandra cautions from an Indian perspective. ${ }^{85}$ For example, Namibia, like in many other monist countries, does require legislative

logically from the content of Article 144' and as this was the pre-constitution position under the common law. Erasmus (n 1$) 100$.

82 R Anderson, 'Redressing Colonial Genocide under International Law: The Hereros' Cause of Action against Germany' (2005) 93 California Law Review 1155, 1159.

83 Tshosa (n 1$) 12$.

84 M Killander, 'The Impact of Transjudicialism on Constitutional Adjudication' In C Fomband, (Ed) The Effects of International Law Norms on Constitutional Adjudication in Africa (OUP 2017) 216.

85 A Chandra, 'India and international law: formal dualism, functional monism' (2017) 57 Indian Journal of International Law 25, 29; E Denza, 'The Relationship Between International and Domestic Law', in M Evans, International Law, 3rd edn (OuP 2010) 417-18. 
sanction for international agreements to be applicable. It is only when the domestic majoritarian check of legislative approval by the National Assembly is given will international agreements have direct effect municipally. Drawing on this, the next section moves away from theoretical constructs to closely examining the practical application of international law by Namibian courts.

\section{$5 \quad$ The Application of International Law by Namibian Courts}

It is settled that international agreements, customary international law, and general principles of law binding upon Namibia would apply automatically unless they contradict the Constitution or legislation. Article 78 of the Constitution enjoins the judiciary to uphold the law, ${ }^{86}$ an obligation that includes international law on the basis of Article 144. Research into the decisions of the superior courts reveals that the courts have rarely analysed the Constitution's international law clause. Further, it is apparent that courts have applied international agreements binding on Namibia with limited reference to customary international law. Further, no substantive engagement with general principles of law can be traced in Namibian decisions. ${ }^{87}$

I will first consider the courts' approach to international agreements. The Namibian courts have favourably and directly relied upon international agreements in domestic decision-making. In Mushwena ${ }^{88}$ the Supreme Court considered the legality of the extradition of 13 accused (who were the respondents) from Zambia after they were apprehended and abducted by Namibian agents. The Court considered the 1966 International Covenant on Civil and Political Rights (ICCPR) and the UN Convention Relating to the Status of Refugees, which were binding on Namibia through accession. O'Linn AJA, commenting on the application of the ICCPR, states:

Not only has it become part of Namibian domestic law by virtue of the Namibian Constitution, but some of its basic principles have been incorporated into the Namibian, Botswana and Zambian laws relating to

86 See also Articles 79(2) and 8o(2) of the Constitution.

87 Cf R Oppong, 'Re-imagining international law: An examination of recent trends in the reception of international law into national legal systems of Africa' (2006) 30 Fordham International Law Journal 300-05. For an application of general principles of EU law in domestic courts, see Armin Cuyvers, 'General Principles of EU Law', in E Ugirashebuja et al., East African Community Law: Institutional, Substantive and Comparative EU Aspects (Brill 2017).

88 Mushwena (n 31). 
extradition, deportation and repatriation. The Convention is also part of international law and breaches of it are not only breaches of the domestic law of these countries, but breaches of international law. ${ }^{89}$

Mushwena thus affirms the direct and automatic application of the international agreements by Namibian courts. Mushwena is similar to the Kauesa ${ }^{90}$ decision of the High Court to the extent that the latter case invokes and applies an international agreement. Kauesa is to be distinguished, however, as it does not directly consider the application of an international agreement but rather invokes it in the interpretation of the Constitution. In Kauesa, the applicant challenged the Regulations to the Police Act that made it an offence for a member of the Namibian Police Force to publicly comment unfavourably upon the administration of the Force or any other government department. In considering whether the provisions of the Regulations fell afoul of the freedom of expression protected under Article 21(1)(a) of the Constitution, the Court considered the African Charter on Human and Peoples' Rights provision on free speech and equality. The Court established that Namibia had acceded to the African Charter thus making it part of binding Namibian law through Articles 143 and 144 of the Constitution. The Court then clarified that:

The specific provisions of the Constitution of Namibia, where specific and unequivocal, override provisions of international agreements which have become part of Namibian law. However, in all situations where such law is not in conflict with the provisions of the Namibian Constitution, such law will have to be given effect to in Namibia. In cases where the provisions of the Namibian Constitution are equivocal or uncertain as to the scope of their application, such provisions of the international

$89 \quad$ Mushwena (n 31) 320 (emphasis added). Similarly, the Supreme Court in Shaanika $v$ City Police (2013) (4) NR 1106 (SC) considers the ICCPR's Article 14 on fair trial rights but does not consider the application of this international instrument in terms of Article 144. Again, in Namunjepo and Others $v$ Commanding Officer, Windhoek Prison and Another 1999 NR 271 (SC) at 281, the Court interpreted torture, cruel, inhumane and degrading treatment in light of the ICCPR and the Convention Against Torture but does not reference Article 144. Cf Chairperson of the Tender Board of Namibia v Pamo Trading Enterprises CC and Another 2017 (1) NR 1 (SC) para [40].

9o Kauesa v Minister of Home Affairs 1994 (NR) 102 (HC). Although the High Court's Kausea decision was appealed to the Supreme Court, the latter did not consider either the African Charter or other rules of international law as a matter of direct effect or interpretation thus making the High Court's decision good authority. See Kauesa $v$ Minister of Home Affairs 1995 NR 175 (SC). See also: Sv Martinez 1993 NR 1 (HC) on the perpetuation of existing international law under the Constitution. 
agreements must at least be given considerable weight in interpreting and defining the scope of the provisions contained in the Namibian Constitution..$^{91}$

Two central principles can be derived from the Kauesa: First, the requirement that the Constitution's provisions can only override international agreements where the former is 'specific and unequivocal' is in line with the common law doctrine of consistent interpretation outlined earlier. Second, Kauesa also affirms the value of international law beyond their direct application domestically: in the interpretation and scoping of Constitutional provisions. This embrace of international law as an interpretative resource, is not textually asserted in the Constitution, as in other jurisdictions. ${ }^{92}$

There has, however, been inconsistency in the direct application of international law by Namibian courts regarding the precedence of the Constitution and legislation. This is illustrated in Mwilima ${ }^{93}$ where the Supreme Court had to consider a contradiction between an international agreement and legislation. Article 14(3)(d) of the ICCPR had obligated the State to provide legal representation in criminal matters to indigent accused persons in the interest of justice. On the contrary, the Legal Aid Act had subjected the provision of legal aid in criminal matters to the availability of resources and funding from the State. ${ }^{94}$ The majority refused to apply the Legal Aid Act as it took the view that it did not give full effect to the rights of an accused as provided for in Article 14(3)(d) ICCPR. ${ }^{95}$ This amounted to a superiorisation of the international agreement provisions over those of legislation, implying that the validity of the latter is to be tested against the former. Article 144 is unambiguous in that both the Constitution and legislation supersede international law including international agreements. ${ }^{96}$ In the least, the Mwilima majority ought to have grappled with interpretatively reconciling the conflicting legislative and treaty provisions per the consistent interpretation principle under common law.

A further inconsistency in the (non-)application of international agreements is revealed in the Supreme Court's Müller ${ }^{97}$ decision. Here, Counsel for the appellant, Mr Müller, relied on international agreements including the Convention on the Elimination of All Forms of Discrimination against Women

\footnotetext{
$91 \quad$ Kauesa (ibid) 140 (emphasis added).

92 Cf section 39(1)(b) of the 1996 South African Constitution.

93 Government of the Republic of Namibia $v$ Mwilima 2002 NR (SC) 235.

94 Mwilima (ibid) 260.

95 ibid.

96 Cf Thudinyane $v$ Edward (SA 17/2005) [2012] NASC 22 [18] (12 October 2012).

97 Müllerv President of the Republic of Namibia \& Another 1999 NR 190 (SC).
} 
(CEDAW) in claiming that he be permitted to adopt his wife's surname and to not be discriminated against on the basis of his sex. Sex is a protected category under Articles 10 and 14 of the Constitution. The Supreme Court, after accepting that Namibia had acceded to and was bound by CEDAW, perplexingly stated: '[s] uch Conventions are of course subject to the Constitution and cannot change the situation, 98 before summarily dismissing the reliance on CEDAW without any attempt at reconciling the Constitution with CEDAW provisions as required by Article $144 .{ }^{99}$

Concerning customary international law's domestic application, there is limited jurisprudence on it as a source of law. Although reference is made to 'international law' by courts, rarely have courts positively identified a rule as one specifically of customary international law. Indicatively, in $S v$ Likanyi, ${ }^{100}$ the Supreme Court was called upon to decide whether the arrest of the accused Mr Likanyi by Namibian agents-while Mr Likanyi was on Botswanan territory-violated the States sovereign act of arrest. ${ }^{101}$ The majority determined that there was a violation of 'international law' through the carrying out of the act of extra-territorial arrest by Namibian agents, which action constituted a prohibited internationally wrongful act. The majority relied upon the Permanent Court of International Justice in SS Lotus. ${ }^{102}$ Although the majority considered and relied on 'international law' to the extent of determining that Namibia engaged in an internationally delinquent act, it did not substantively engage Article 144 to determine whether the prohibition stems from international agreements, or customary international law or, for that matter, general principles of law. Further, the majority erred in its failure to take note of another potential customary international law rule: State consent would preclude the wrongfulness of an internationally delinquent act. ${ }^{103}$ This rule is reflected in the International Law Commission (ILC) Articles on Responsibility

$98 \quad$ Müller (ibid.) at 205. Further Namibian decisions that consider international agreements: Namunjepo \& Others $v$ Commanding Officer, Windhoek Prison \& Another 1999 NR 271 (SC); Ex parte Attorney General: In Re Corporal Punishment by Organs of State 1991 NR 178 (SC). See Dausab (n 1 ) 261.

99 Similarly, The Chairperson of the Immigration Selection Board v Frank 2001 NR 107 (SC). N Horn, 'International human rights norms and standards', in N Horn and A Bösl (eds) Human rights and the rule of law in Namibia (Macmillan Education Namibia 2008) 144.

$100 \quad$ SvLikanyi 2017 (3) NR 771 (SC).

101 Likanyi (n 100) para [68]-[69].

102 SS Lotus (Francev Turkey) 1927 PCIJ (Ser. A) No. 10 at 28 (September 7). Likanyi (n 100) para [110].

103 See N Ndeunyema, 'Extra-territorial arrests by States: Did the Namibian Supreme Court get it wrong?' (OxHRH Blog, 31 August 2017) <http://ohrh.law.ox.ac.uk/extra-territorial -arrests-by-states-did-the-namibian-supreme-court-get-it-wrong/>. 
of States for Internationally Wrongful Acts, ${ }^{104}$ which Articles are widely regarded as reflecting customary international law. ${ }^{105}$ This reveals that Namibian courts rarely explicitly identify and apply customary international law rules as part of Namibian law. ${ }^{106}$

These cases reveal the inconsistencies, inaccuracies and divergences in the application of international law domestically. Namibian Courts, where the opportunity arises, clearly ought to pursue a rigorous analysis of the ambit and application of Article 144. Notably, the Supreme Court in South African Poultry Association $v$ Minister of Trade and Industry ${ }^{107}$ had heard submissions by counsel on the application of Article 144 in the context of international trade agreements such as the 2002 Southern African Customs Union Agreement and the 1992 Southern African Development Community Agreement, and their enforcement in Namibian courts. ${ }^{108}$ However, it determined that it would 'deliberately refrain from expressing [itself] on the merits at all, ${ }^{109}$ and rather remitted the matter to the High Court for thorough examination.

\section{$6 \quad$ Interpretative Methodology and Soft Law Resources}

Given the determination that international agreements are directly binding on Namibian law, subject to the stated exceptions, it is necessary to analyse the appropriate methodology to be applied in the interpretation of international agreements domestically. From a practical perspective, the determination of a legally coherent and legitimate interpretative methodology is critical. Due to the fact that international agreements are negotiated by a variety of States with divergent interests, treaty provisions are often framed generally, vaguely and attract ambiguity as to their meaning. From a doctrinal and normative

104 UN Doc A/Res/56/83, Annex, UN Doc A/CN.4/L.6o2/Rev.1, GAOR 56th Session Supp 10, 43 (specifically Articles 2-4).

105 S Talmon, 'The responsibility of outside powers for the acts of secessionist entities' (2009) 58 International and Comparative Law Quarterly 495.

106 In the early jurisprudence of the Constitution, the Corporal Punishment (n 98), the Supreme Court could have but did not express a position on whether the corporal punishment's prohibition had matured into customary international human rights law. As Tshosa holds, this failure by the Court was a missed opportunity to determine the status of customary international law in Namibia early on in Namibia's constitutional development. Tshosa (n 1). Cf Cultura 2000 (n 39).

107 South African Poultry Association and Others $v$ Minister of Trade and Industry and Others 2018 (1) NR 1 (SC). See also Zongwe (n 1 ) 97.

108 ibid. para [41].

109 ibid. para [69]. 
perspective, determining a widely acceptable interpretative methodology avoids claims that norms such as human rights are premised upon questionable interpretative principles and as such are results driven. Norms that rely upon the implied rights doctrine are acutely vulnerable to this critique which invite accusations of 'promiscuous rights manufacture.'110 This heightens the necessity of relying upon irreproachable legal methods in interpreting international law. ${ }^{111}$

Moreover, in interpreting and applying binding international law domestically, reliance may be placed upon sources that are a step away from being legally binding law, i.e. soft law sources. It is thus necessary to determine the authoritative status and relevance of soft law sources in Namibian courts.

\subsection{Interpreting International Agreements in Namibian Courts}

In this section, we turn to consider the how of interpreting international agreements in Namibian courts. The issues are germane as, while international agreements may have direct application in Namibia, the meaning of international agreement provisions are often disputed. Further, Kausea affirms the parallel interpretative function of international law in Namibia. In determining the appropriate method and techniques for interpreting international agreements by Namibian courts, two possibilities are offered: First, the rules of interpretation developed through judicial decisions for interpreting the Constitution and domestic legislation; second, the rules of interpretation developed under international law to specifically interpret international agreements. The latter proposition is reflected in Articles 31 and 32 of the VCLT. An exception would be where a given international agreement specifically predetermines the interpretative rules that are applicable.

Whether a municipal court would be legally bound to apply the VCLT's interpretative rules is a matter determined by domestic law. On this premise, customary international law is part of binding Namibian law. There need not be two or more State parties to a dispute inviting the interpretation of an international agreement for the methodology of Articles 31 and 32 VCLT to be applicable.

There is no evidence of Namibian ratification of the VCLT. ${ }^{12}$ Nevertheless, there is little dispute that Articles 31 and 32 VCLT reflect norms of customary

110 D Luban, 'The Warren Court and the Concept of a Right' (1999) 34 Harvard Civil RightsCivil Liberties Law Review 14.

111 T Meron, Human Rights and Humanitarian Norms as Customary Law (Clarendon Press 1989) 81.

112 In $S v$ Martinez 1993 NR 1 (HC) the High Court, in determining the binding effect of the 1982 UN Convention on the Law of the Sea on Namibia, considered whether the UN 
international law. This proposition finds abundant support, including in the ICJ's Kasikili/Sedudu Island ${ }^{113}$ decision concerning the Namibia/Botswana boundary, where Namibia's agents asserted—and the ICJ accepted-that Articles 31 and 32 VCLT as customary international law.

Namibian courts have rarely referenced, let alone thoroughly considered, these rules in their application or interpretation of international agreements. Nonetheless, I argue that there exists a legal obligation upon Namibian courts to apply Articles $3^{1}$ and $3^{2}$ as a matter of binding customary international law. ${ }^{114}$ To augment this, the Namibian Supreme Court has taken a strict position to respect international law in the municipal setting based on its fidelity to the rule of law as a founding Constitutional principle. In Likanyi, Shivute CJ affirmed:

The rule of law requires that even people accused of committing heinous crimes must be dealt with according to law. Where a person is brought before court in violation of international law, the rule of law - a foundational principle of the Constitution - requires that a court critically examine the conduct of the law enforcement agency in securing the presence of the accused within the territorial jurisdiction of the court. ${ }^{115}$

While Shivute's emphasis upon the centrality of international law to respect for the rule of law is in the context of substantive rules of international law, this also extends to quasi-procedural rules, such as the interpretative methodology in Articles 31/32 VCLT interpreting international agreements.

Beyond legal justifications for applying the Articles $31 / 3^{2}$ as custom, there are normative and policy-based reasons why municipal (Namibian) courts ought to apply the VCLT domestically. First is harmonisation; there remains divergent approaches between States, and amongst international law judges and

Council for Namibia had signed the VCLT on Namibia's behalf, but was unable to establish the question conclusively.

113 Kasikili/Sedudu Island (Botswana v Namibia) Judgment, Merits [1999] ICJ Rep 1045 [18]. See also Memorial Submitted by the Namibian Government [46]. Available from: <http:// www.icj-cij.org/files/case-related/98/8574.pdf >; Oil Platforms (Islamic Republic of Iran v United States of America) Preliminary Objections, Judgment [1996] ICJ Reports (II) [23]; R Gardiner, Treaty Interpretation (OuP 2008) 12; M Villiger, Customary International Law and Treaties: A Study of Their Interactions and Interrelations with Special Consideration of the 1969 Vienna Convention on the Law of Treaties (Martinus Nijhoff 1985) 484-506.

114 A Nollkaemper, 'Grounds for the Application of International Rules of Interpretation in National Courts' in H Aust and G Nolte, The Interpretation of International Law by Domestic Courts: Uniformity, Diversity, Convergence (OUP 2013) 37.

115 Likanyi (n 100) [8]. 
scholars as to the element(s) that ought to be relevant in treaty interpretation. One set emphasises the subjective intentions of the parties (including through liberal recourse to travaux préparatoires), ${ }^{116}$ and another group ascribes a significant premium to a treaty's object and purpose, while others stress the primacy of the text with limited scope for bringing in extrinsic evidence about the intentions of the parties and a treaty's object and purpose. ${ }^{117}$ The utility of Articles $31 / 3^{2}$ lies in the fact that it offers a common approach—or at the least, a common starting point - to interpreting international agreements. 'Common' in this context is, however, not to be understood as singular, as Articles 31/32 indeed reflects an eclectic mix of interpretative approaches. ${ }^{118}$

Second is legitimacy. Particularly where the legitimacy of a municipal court to determine certain legal issues is tenuous, it may be appealing to turn to the VCLT's interpretative methodology. This immunizes municipal courts from criticisms that interpretations formulated may generate in relation to usurping the executive and legislative roles. For example, interpretative legitimacy concerns would be of potentially heightened relevance in the context of positive rights and duties of social-economic nature (water, food, housing) where institutional justiciability objections as to the legitimacy of judges in adjudicating matters laden with policy, resource and budgetary considerations are likely to arise. Waibel advances the use of the VCLT approach as particularly appealing to judges in countries in transition; arguably, Namibia remains 'transitional' considering the sparse reliance upon international law domestically. ${ }^{119}$

The third is practicality. While Articles 31/32 may be deemed as being primarily addressed to State parties in light of the language employed, it has also been claimed that the VCLT drafters had municipal courts in mind as addressees. Waibel cites the normative desirability of legal certainty and the need for convergence in treaty interpretation which were discussed by the ILC and Vienna Conference that drafted the VCLT. ${ }^{120}$ Waibel points out that national courts were implicitly a central audience for the VCLT's interpretive rules as the ILC had discussed the issue based on reports that summarised interpretive practices that included many decisions of national courts. ${ }^{121}$ Many early writings also examine treaty interpretation, as well as the law of treaties more broadly, from the perspective of national practice. Moreover, even in the

116 M Waibel, 'Principles of Treaty Interpretation: Developed for and Applied by National Courts?' in Aust and Nolte (n 114) 10-11 (internal footnotes omitted).

117 ibid.

118 J Tobin, The Right to Health in International Law (Oxford 2012) 79.

119 Waibel (n 116) 16.

120 Waibel (n 116) 13.

121 ibid. 
absence of explicit consideration of national courts as one important audience, the VCLT's drafters were seemingly aware that the audience was broad and that a range of diverse treaty interpretation would apply Articles 31/32. ${ }^{122}$

\subsection{The Status and Application of Non-binding International Law Sources in Domestic Interpretation}

In interpreting and applying hard law-whether derived from the Constitution, or legislation, or from international law — reference may be made to those interpretation within various sources that are a step away from being legally binding: soft law. ${ }^{123}$ Soft law may take forms that include general comments, general recommendations or resolutions, and are often issued by quasijudicial or non-judicial bodies such as the Committee on Economic Social and Cultural Rights (CESCR), the African Commission on Human and Peoples' Rights, or the Committee on the Elimination of Racial Discrimination and Discrimination Against Women, etc. Soft law sources are to be distinguished from comparative law sourced from foreign decisions (including foreign regions), and which may attract persuasive authority within Namibian judicial reasoning. ${ }^{124}$

The significance of soft law lies in potentially aiding interpretation, particularly where legal provisions are vague, contestable, ambiguous or openended. ${ }^{125}$ While it is settled that soft law sources are not legally binding of and by themselves, their persuasiveness and authoritative weight requires attention. These concerns are not entirely new. The nature, drafting technique and legitimacy of soft law sources has been the subject of scholarly analysis, perhaps more prominently by Keller and Grover in the context of general comments of the UN Human Rights Committee. ${ }^{126}$ The issues Keller and Grover raise in their analysis mirror those arising from soft law issued by other bodies such as the CESCR and African Commission, as well as other soft law instruments at the disposal of domestic courts. ${ }^{127}$

Reactions to general comments lie at different levels of the "binding authority" spectrum. At the two opposite ends of this spectrum are those who support

\footnotetext{
122 ibid; A Nollkaemper, 'Grounds for the Application of International Rules of Interpretation in National Courts' in Aust and Nolte (n 114) 37.

123 See A Boyle and C Chinkin, The Making of International Law (oup 2007) 211.

124 See Attorney General v Minister of Justice Supreme Court of Namibia 2013 (3) NR 806 (SC).

125 P Alston, 'The Historical Origins of the Concept of 'General Comments', L de Chazournes and V Gowlland-Debbas (eds) The International Legal System in Quest of Equity and Universality: Liber Amicorum Georges Abi-Saab (Martinus Nijhoff 2001) 763.

126 H Keller and L Grover, 'General Comments of the Human Rights Committee and Their Legitimacy' in H Keller and G Ulfstein, (eds) UN Human Rights Treaty Bodies: Law and Legitimacy (CUP 2012) 118.

127 Ibid.
} 
their use as 'authoritative interpretations' of treaty norms, while others reject their use entirely as 'broad, unsystematic, statements which are not always well founded, and are not deserving of being accorded any particular weight in legal settings'. Some States have also been on record as objecting to some general comments, asserting that their content is an 'unacceptable attempt to attribute to treaty provisions a meaning which they do not have.'128 Similar criticism is exemplified by those who admonished the CESCR's General Comment No. $15^{129}$ that implied the human right to water from Articles 11 and 12 of the International Covenant on Economic, Social and Cultural Rights. ${ }^{130}$ Nevertheless, the normative legitimacy of general comments ought to be assessed through their quality of reasoning, language and process for drafting general comments, all of which would impact their persuasiveness, and interpretative and deliberative resourcefulness.

Two principal theories can thus be advanced in justifying recourse to general comments to treaties. The first is the subsequent practice theory. This theory views general comments as constituting subsequent practice for purposes of Article 31(3)(b) VCLT and can thus be taken into account in interpreting an international agreement (less so where a State has contested the general comment's content). Relatedly, the acquiescence of States parties to general comments would. The argument is that, per Article 31(1) VCLT, a good faith interpretation of an instrument obliges States parties to duly consider the content of general comments, as they are the product of a body established to interpret such an instrument, as well as to monitor and promote compliance with it. The proposition is for Article 31(1)(c) VCLT to be interpreted more broadly to include the practice of treaty monitoring bodies and not only States themselves as has been the tradition in interpreting international law. ${ }^{131}$

Second is the authoritative interpretation theory. Where general comments are asserted as 'authoritative' interpretations or statements of a treaty. Their authoritativeness refers to the fact that treaty body committee members are elected to perform duties specified and to do so implies that they need to adopt general comments. ${ }^{132}$ Authoritativeness may also derive from the expertise of committee members. The soft law character of general comments does not devoid them of any and all legal significance. They are particularly useful in both domestic and supra-national settings where there are attempts to resolve

\footnotetext{
128 ibid 119.

129 'General Comment 15: The Right to Water' (Articles 11 and 12 of the Covenant) (2002) UN Doc E/C 12/2002/11.

130 S Tully, 'A Human Right to Access Water? A Critique of General Comment No 15' (2005) 23

(1) Netherlands Quarterly of Human Rights 35.

131 Langford (n 129) 435; Keller and Grover (n 126) 132.

132 Keller and Grover (n 126) 132.
} 
'hard cases' by setting out important background principles against which a law may be analysed. ${ }^{133}$ Indeed, what is unassailable from general comments is that they often reflect a robust legal analytical function that advances a common international understanding of treaties and serves to prevent State parties from claiming that a treaty obligation is limited to this or that area of its experience. ${ }^{134}$

Therefore, on the combined strength of the subsequent practice and authoritative interpretation theories, soft law sources such as general comments can legitimately be relied upon in legal interpretation by Namibian courts. While being aware of their legally non-binding nature, courts ought to consider soft law as resources that offer deliberative, interpretative, and potentially persuasive value. This aligns with the international law-friendly disposition that pervades the Constitution.

\section{7}

Conclusion

In the analysis of the application of international law in Namibia, this paper has determined that, subject to constitutional and legislative superiority, Article 144 directly incorporates international agreements and general rules of public international law as part of binding Namibian law. The latter source being constituted of both customary international law and general principles of law. Further, in interpreting international agreement, rules of interpretation established under custom, as reflected in Article 31/32 VCLT, apply. Namibian courts can also legitimately, yet judiciously, rely upon soft law sources as aid to interpretation or as persuasive authority. The paper's critique of the Namibian Supreme Court's jurisprudence on international law reveals a troubling non-, under- and mis-application of binding international law. The Supreme Court should be at the forefront in the interpretation and the application of international law domestically, commencing with an authoritative determination of the meaning and scope of Article 144. Namibia is at the forefront of States that are parties to treaties, many of which concern international human rights law. Beyond rule of law and legal certainty imperatives, the need and urgency for an enhanced understanding of international law's municipal application lies in the potential to domestically serve as both a mighty sword and protective shield in the pursuit of human rights law for all.

133 ibid 129.

134 ibid 124. 